Michat Toruński, Filip Gotba

\title{
Ściganie karne w Unii Europejskiej przed i po Traktacie z Lizbony - wybrane zagadnienia
}

\section{Wprowadzenie}

Aktualne działania legislacyjne Unii Europejskiej, których podstawa prawna znajduje się w tytule $\mathrm{V}$ rozdziału 4 Traktatu o funkcjonowaniu Unii Europejskiej ${ }^{1}$ "Współpraca wymiarów sprawiedliwości w sprawach karnych", stanowią część szerszego zjawiska internacjonalizacji prawa karnego, wyodrębniania europejskiego prawa karnego ${ }^{2}$, a ściślej rzecz ujmując, unijnego prawa karnego. Ukazują one zmianę charakteru tej gałęzi prawa, która dotychczas była wytworem przede wszystkim krajowych porządków prawnych.

Należy zwrócić uwagę, że pomimo postępującej integracji w ramach struktur Unii Europejskiej w dziedzinie prawa karnego brak jest obecnie w obowiązującym porządku prawnym podstawy do całkowitego przekazania organom unijnym kompetencji do stanowienia norm prawnokarnych zarówno w dziedzinie prawa materialnego, jak i procesowego. Wynika to przede wszystkim ze statusu prawnego Unii Europejskiej oraz jednej z podstawowych zasad jej funkcjonowania zasady przyznania, o której mowa w art. 5 Traktatu o Unii Europejskiej³. Przypomnieć trzeba, że Unia Europejska - jako organizacja międzynarodowa, której państwa członkowskie przekazały do wykonania pewne kompetencje - działa wyłącznie w granicach kompetencji przyznanych

${ }^{1}$ Dz.Urz. UE C 326 z 26 X 2012 r., dalej „TFUE”.

${ }^{2}$ Na temat tego procesu zob. więcej w: Europejskie prawo karne, pod red. A. Grzelak, M. Królikowskiego, A. Sakowicza, Warszawa 2012, s. 1-26.

${ }^{3}$ Dz.Urz. UE C 326 z 26 X 2012 r., dalej „TUE”. 
jej przez te państwa w traktatach do osiągnięcia określonych w nich celów. W przypadku dziedziny, o której mowa w art. 4 ust. 2 lit. j TFUE, czyli przestrzeni wolności, bezpieczeństwa i sprawiedliwości, traktaty przyznają Unii kompetencję dzieloną z państwami członkowskimi, co oznacza, że zarówno Unia, jak i państwa członkowskie mogą stanowić prawo i przyjmować akty prawnie wiążące $w$ tej dziedzinie (art. 2 ust. 2 TUE). Tym samym należy stwierdzić, że kompetencja Unii Europejskiej do stanowienia prawa w dziedzinie przestrzeni wolności, bezpieczeństwa i sprawiedliwości nie ma charakteru ekskluzywnego.

Abstrahując od uzasadnienia normatywnego wskazanego stanu rzeczy, poddając analizie zjawisko tworzenia się europejskiego prawa karnego, trzeba pamiętać, że prawo karne in genere jest obszarem newralgicznym, bardzo delikatnym. Prawo, przynajmniej w swej podstawowej części, wynika z założeń moralnych i jest nastawione na ochronę wartości ocenianych dodatnio w kategoriach moralnych danego społeczeństwa ${ }^{4}$. Delikatność materii regulowanej przez prawo karne jest konsekwencją spornego charakteru wielu spośród wartości chronionych przez tę gałąź prawa oraz zasadniczych różnic w ocenach moralnych pomiędzy różnymi społeczeństwami.

Zważywszy na przedstawione powyżej obserwacje, wypada wskazać, że "ustawodawca unijny", przedsiębiorąc działania legislacyjne na omawianej tutaj płaszczyźnie, musi za każdym razem zważać nie tylko na ograniczenia wynikające $\mathrm{z}$ zasady przyznania, a zatem wystrzegać się przekroczenia kompetencji przyznanych przez traktaty, ale również, a może przede wszystkim, winien zwracać uwagę na kulturową i społeczną charakterystykę państw członkowskich, w których podejmowana jest prawodawcza aktywność.

Poczyniona uwaga jest szczególnie istotna w świetle faktu wyposażenia Unii Europejskiej po wejściu w życie Traktatu z Lizbony ${ }^{5}$ - w zakresie przywołanej tutaj "Współpracy sądowej w sprawach karnych" - w nowe, nieznane dotąd na tej płaszczyźnie instrumenty prawne, które już obecnie mają realny i bezpośredni wpływ na krajowe regulacje karnoprawne. Ponadto, obserwując dalsze zamierzenia Unii - politykę zmierzającą do

${ }^{4}$ T. Hanausek, S. Pikulski, Problem stosowania podstępu w działaniach kryminalistycznych, "Studia Kryminologiczne, Kryminalistyczne i Penitencjarne” 1991, t. 21, s. 299-300. Podobnie: A. Zoll, Europäisierung des Strafrechts aus der polnischen Sicht, "Zeitschrift für die Gesamte Strafrechtswissenschaft" 2006, s. 749-750, gdzie autor stwierdza, że prawo karne związane jest z kulturą społeczeństwa, a jego specyficzna rola polega na wyznaczaniu granic ingerencji państwa w dobra jednostki.

${ }^{5}$ Dz.U. 2009 Nr 203, poz. 1569, dalej „TzL”. 
utrzymania i rozwoju przestrzeni wolności, bezpieczeństwa i sprawiedliwości ${ }^{6}$ - należy prognozować, że oddziaływanie to będzie coraz silniejsze. Chodzi tu przede wszystkim o wprowadzoną za sprawą Traktatu z Lizbony możliwość ustanawiania w drodze dyrektyw norm minimalnych m.in. $\mathrm{w}$ dziedzinie praw jednostek w postępowaniu karnym oraz praw ofiar przestępstw, jak również kompetencję do harmonizacji kar minimalnych.

Niniejszy artykuł ma na celu omówienie wybranych zagadnień dotyczących regulacji ścigania karnego na gruncie prawa Unii Europejskiej. Biorąc pod uwagę fakt, iż obecny kształt tej regulacji jest wynikiem trwającego kilkadziesiąt lat procesu, na który składały się zarówno rozmaite działania prawodawcze: zawieranie umów międzynarodowych oraz wydawanie aktów wtórnego prawa wspólnotowego i unijnego, jak również różne formy współpracy międzynarodowej niemającej charakteru prawodawczego, opracowanie nie ogranicza się do omawiania obecnego stanu europejskiego ścigania karnego, ale uwzględnia także historyczny opis powstania poszczególnych instytucji.

W pierwszej jego części zostanie przedstawiony krótki rys historyczny instrumentarium zwalczania przestępczości ${ }^{7}$, którym dysponowała Unia Europejska, a wcześniej Wspólnota, przed wejściem w życie Traktatu z Lizbony. Podjęta zostanie też próba ukazania skali postępu, jaki dokonał się w tym zakresie na przestrzeni ostatnich lat. Następnie zostaną omówione wybrane zagadnienia harmonizacji przepisów dotyczących praw procesowych osób podejrzanych oraz oskarżonych w postępowaniu karnym. Zasygnalizowane zostanie także zagadnienie norm minimalnych odnoszących się do kar. Ostatnia część artykułu jest poświęcona próbie oceny, czy obrana przez państwa członkowskie w postlizbońskiej rzeczywistości ścieżka internacjonalizacji prawa karnego jest zasadna.

\section{Europejskie ściganie karne przed wejściem w życie Traktatu z Lizbony}

Podwalin unijnego prawa karnego należy doszukiwać się w grupie współpracy, którą postanowiono powołać do życia w grudniu $1975 \mathrm{r}$. w Rzymie, podczas nieformalnego spotkania ministrów sprawiedliwości

${ }^{6}$ Zob.np.pkt 1 Preambuły do dyrektywy Parlamentu Europejskiego i Rady 2012/13 z dnia 22 V 2012 r. w sprawie prawa do informacji w postępowaniu karnym, Dz.Urz. UE L 142 z 1 VI 2012 r.

${ }^{7}$ A. Górski używa w tym kontekście pojęcia "prawo europejskiego ścigania karnego", zob. A. Górski, Europejskie ściganie karne. Zagadnienia ustrojowe, Warszawa 2010, s. 30-36. 
i ministrów spraw wewnętrznych wszystkich państw członkowskich Wspólnot Europejskich ${ }^{8}$. Działalność grupy TREVI (franc. Terrorisme, Radicalisme, Extremisme, Violence Internationale ${ }^{9}$ ) polegała na spotkaniach ministrów spraw wewnętrznych, innych wyższych urzędników, w szczególności policyjnych oraz ekspertó $\mathrm{w}^{10}$, które miały na celu przede wszystkim omawianie kwestii związanych ze zwalczaniem międzynarodowego terroryzmu oraz handlu narkotykami ${ }^{11}$. Do najważniejszych efektów współpracy w ramach grupy TREVI można zaliczyć przygotowanie założeń konwencji o utworzeniu Europejskiego Urzędu Policji. Trzeba podkreślić, że grupa miała nieformalny charakter, działała bez jakichkolwiek podstaw prawnych, opinia publiczna nie miała dostępu do informacji na temat jej działań, a nawet do treści podjętych w jej ramach decyzji, który miały charakter niejawny.

Rozszerzeniem, a zarazem sformalizowaniem współpracy w omawianym obszarze było podpisanie w 1985 r. Układu z Schengen, który znosił kontrolę graniczną w celu realizacji swobody przepływu osób na terytorium państw członkowskich układu. Państwa-sygnatariusze podpisujący traktat zdawały sobie sprawę, że otwarcie granic dla turystów czy też pracowników oznaczało w równym stopniu otwarcie ich dla przestępców. Z tej przyczyny, na mocy podpisanej dnia 19 czerwca 1990 r. Konwencji Wykonawczej do Układu z Schengen wprowadzono między innymi tak zwane „środki wyrównawcze”, które miały na celu rekompensować zniesienie wewnętrznej kontroli granicznej pomiędzy państwami strefy Schengen. Polegały one na usprawnieniu oraz wzmacnianiu współpracy i działań koordynujących między organami policji i sądami państw-sygnatariuszy. Jednym z najważniejszych spośród tych środków ${ }^{12}$ był działający od 1995 r. ${ }^{13}$ System Informacyjny Schengen

${ }^{8}$ A. Grzelak, T. Ostropolski, Przestrzeń wolności, bezpieczeństwa i sprawiedliwości Unii Europejskiej: wspótpraca policyjna i sądowa w sprawach karnych, Warszawa 2009, s. XI.1-3.

${ }^{9}$ Choć nieoficjalnie wskazuje się, że nazwa grupy pochodzi od słynnej fontanny w Rzymie, gdzie miało dojść do pierwszego porozumienia jej członków.

${ }^{10}$ A. Grzelak, Trzeci filar Unii Europejskiej, Warszawa 2008, s. 24.

${ }^{11}$ Więcej na temat działalności grupy TREVI oraz jej roli w formalizacji współpracy w dziedzinie spraw karnych zob. m.in. w: J.D. Occhipinti, The Politics of EU Police Cooperation: Toward a European FBI?, London 2003, s. 29-51; J. Van Oudenaren, Uniting Europe: An Introduction to the European Union, Lanham 2005, s. 232-238; A. Gruszczak, III filar Unii Europejskiej po Tampere: wnioski i perspektywy, "Studia Europejskie” 2000, nr 3, s. 2-3.

${ }^{12}$ E. Brouwer, Digital Borders and Real Rights: Effective Remedies for Third-Country Nationals in the Schengen Information System, seria Immigration and Asylum Law and Policy in Europe, Leiden 2008, s. 49.

${ }^{13}$ Ibidem, s. 1. 
(ang. Schengen Information System), czyli baza danych, która używana była w celu wymiany informacji na temat określonych kategorii osób oraz przedmiotów. Do kategorii osób, których dane wprowadzane były do Systemu Informacyjnego Schengen, zaliczały się: osoby poszukiwane do aresztowania ekstradycyjnego, cudzoziemcy, którym odmawia się wjazdu ze względu na stwarzane przez nich zagrożenie dla porządku publicznego, bezpieczeństwa publicznego lub bezpieczeństwa narodowego, niektóre osoby zaginione, osoby będące świadkami, osoby wezwane do stawienia się przed sądem $\mathrm{w}$ związku z postępowaniem karnym zmierzającym do pociągnięcia ich do odpowiedzialności karnej, osoby mające odbywać wyrok w sprawie karnej, a także osoby, których dane wpisywane są do celów niejawnego nadzoru lub szczególnych kontroli. Oprócz danych osób do systemu można było wpisywać dane określonych kategorii przedmiotów potrzebne do ich zajęcia lub wykorzystania w charakterze dowodu w postępowaniu karnym. Mogły to być przedmioty takie jak podejrzane banknoty, a także skradzione, wykorzystane w niewłaściwy sposób lub utracone: pojazdy silnikowe, przyczepy i naczepy, broń palna, urzędowe blankiety oraz dokumenty tożsamości. Oprócz tego wprowadzało się też dane pojazdów osób, których dane zostały wpisane w celu prowadzenia niejawnego nadzoru lub szczególnych kontroli.

Dnia 1 listopada 1993 r. wszedł w życie Traktat z Maastricht, na mocy którego powstała Unia Europejska. Jej działanie miało opierać się na strukturze filarowej. Traktat o Unii Europejskiej przewidywał trzy filary, z których trzeci nosił nazwę „Postanowienia o współpracy w dziedzinie wymiaru sprawiedliwości i spraw wewnętrznych". Obejmował on między innymi takie dziedziny, jak: współpraca sądowa w sprawach karnych i cywilnych, współpraca celna czy azylowa. Wraz z wejściem w życie traktatu zakończyła działalność grupa TREVI ${ }^{14}$.

W jaki sposób powinno się wytłumaczyć tendencję do stopniowego rozszerzania i formalizowania kooperacji w dziedzinie spraw karnych, poczynając od wspomnianej współpracy w zakresie grupy TREVI, a kończąc na Traktacie z Maastricht? Przyczyn tego zjawiska można wskazać kilka, w szczególności jednak należy zwrócić uwagę na przekonanie państw członkowskich Unii, że cele Wspólnoty, przede wszystkim integracja ekonomiczna, mogły zostać osiągnięte wyłącznie w przypadku paralelnego zapewnienia odpowiednich instrumentów wewnętrznego

${ }^{14}$ A. Grzelak, T. Ostropolski, op. cit., s. XI.1-3. 
bezpieczeństwa, które miały chronić obywateli przed negatywnymi skutkami ubocznymi swobody przepływu osób. Nie można ponadto nie wspomnieć o przyczynach zewnętrznych, wśród których na pierwszym miejscu wypada wyeksponować rosnący problem terroryzmu oraz handlu narkotykami, który bez wątpienia nasilał się w latach osiemdziesiątych XX w.

Analizując współpracę $w$ trzecim filarze, trzeba brać pod uwagę jej specyfikę, która przejawiała się między innymi w tym, że miała ona charakter międzyrządowy, a nie wspólnotowy ${ }^{15}$. Jurysdykcja Trybunału Sprawiedliwości Wspólnot Europejskich (TS WE), która zastała mu przyznana dopiero w Traktacie amsterdamskim (co do zasady), była w tym zakresie w znacznym stopniu ograniczona, a zasada lojalności nie była expressis verbis wyrażona.

Należy odnotować ze smutkiem, że współpraca w ramach trzeciego filaru okazała się nieskuteczna. Przyczyn tego stanu rzeczy można upatrywać między innymi $w$ charakterze instrumentów prawnych wprowadzonych przez Traktat $\mathrm{z}$ Maastricht $\mathrm{w}$ analizowanym obszarze. Instrumentami tymi były bowiem: wspólne stanowiska, wspólne działania oraz konwencje.

Pierwszy spośród tych instrumentów, czyli wspólne stanowiska, był instrumentem mającym na celu ustalenie sposobu postępowania Unii w określonej sprawie, zazwyczaj polegającego na zajęciu stanowiska w negocjacjach w sprawie umowy międzynarodowej, której stroną miały być państwa członkowskie ${ }^{16}$. Przepis stanowiący ich podstawę prawną pozwalał Radzie "przyjmować wspólne stanowiska i wspierać, przy użyciu stosownej formy i według właściwych procedur, wszelką współpracę przyczyniającą się do osiągnięcia celów Unii"17. Niestety, nie ma zgody wśród przedstawicieli doktryny co do wiążącego charakteru wspólnych stanowisk. Formułowane są argumenty przemawiające zarówno za, jak i przeciw wiążącym skutkom skorzystania z tego instrumentu. Rozstrzygnięcie tego sporu było szczególnie problematyczne również dlatego, że różne wersje językowe traktatu sugerowały odmienne rozwiązania. Kontrowersja ta miała jednak stosunkowo niewielkie znaczenie praktyczne ze względu na małą liczbę przyjętych wspólnych stanowisk ${ }^{18}$.

\footnotetext{
${ }^{15}$ Zwraca na to uwagę A. Gruszczak, op. cit., s. 1.

16 A. Grzelak, op. cit., s. 219-220.

17 Dz.Urz. UE C 191 z 29 VII 1992 r.

${ }_{18}$ A. Grzelak, op. cit., s. 220-222.
} 
Wspólne działania mogła przyjąć Rada w zakresie, w jakim cele Unii mogły być lepiej osiągnięte pod względem skali lub przewidywanego efektu działania przez wspólne działanie niż przez państwo członkowskie działające samodzielnie. Instrumenty te nie miały skutku bezpośredniego, a ich moc obowiązująca również budziła wątpliwości ${ }^{19}$. Służby prawne Rady początkowo uznawały wspólne działania za wiążące, jednak pogląd ten nie był akceptowany przez państwa członkowskie. W konsekwencji służby prawne złagodziły swoje stanowisko, uznając, że nie można stwierdzić, iż wszystkie wspólne działania mają charakter wiążący, ale należy oceniać in concreto charakter każdego takiego aktu, biorąc pod uwagę jego treść oraz użyte w nim sformułowania. Wątpliwości, jakie narosły wokół wspólnych działań, doprowadziły do zlikwidowania tego instrumentu przez Traktat amsterdamski (przy zachowaniu w mocy wspólnych działań przyjętych do tamtej pory $)^{20}$.

Dopiero trzeci spośród instrumentów - konwencja - miał charakter wiążący. Zgodnie z art. K.3 ust. 2 lit. c) Rada mogła zredagować tekst konwencji i zarekomendować jej przyjęcie państwom członkowskim. Były to zatem klasyczne umowy międzynarodowe, świadczące o międzyrządowym charakterze współpracy w ramach trzeciego filaru. Pomimo że konwencje były w zasadzie aktami prawa międzynarodowego publicznego, już Traktat z Maastricht pozwalał na poddanie ich jurysdykcji TS WE. Musiało to być jednak przewidziane w samym tekście danej konwencji. Niestety, konwencje nigdy nie stały się efektywnym instrumentem polityki karnej Unii Europejskiej, przede wszystkim ze względu na konieczność ich czasochłonnej ratyfikacji przez wszyst$k^{21}{ }^{21}$ państwa członkowskie. Przykładowo, dwie konwencje dotyczące procedur ekstradycyjnych: konwencja z dnia 10 marca 1995 r. w sprawie uproszczonej procedury ekstradycyjnej między państwami członkowskimi Unii Europejskiej oraz konwencja z dnia 27 września 1996 r. odnosząca się do ekstradycji między państwami członkowskimi Unii Europejskiej, nie weszły w życie, ponieważ nie zostały ratyfikowane przez odpowiednią liczbę państw członkowskich ${ }^{22}$.

Reakcją na bolączkę nieskuteczności miał być Traktat amsterdamski podpisany w 1997 r., który znacząco poszerzał współpracę w trzecim

${ }^{19}$ Ibidem, s. 42.

${ }^{20}$ Ibidem, s. 222-224.

${ }^{21}$ A. Grzelak, T. Ostropolski, op. cit., s. XI.1-30.

${ }^{22}$ P. Szarek-Mason, The European Union's Fight Against Corruption: The Evolving Policy Towards Member States and Candidate Countries, Cambridge 2010, s. 108-109. 
filarze, przemianowując go na „Postanowienia o współpracy policyjnej i sądowej w sprawach karnych". Jedną z najważniejszych zmian, jakie przewidywał, było wprowadzenie nowego instrumentu prawnego decyzji ramowej, której charakter prawny był zbliżony do charakterystycznej dla współpracy w pierwszym filarze dyrektywy. Choć nie obowiązywała ona bezpośrednio, wiązała państwa członkowskie Unii Europejskiej co do rezultatu, który miał być osiągnięty, pozostawiając jednak w ich gestii formę i środki implementacji ${ }^{23}$. Jako przykład przyjętych przez Unię decyzji ramowych dotyczących omawianej w artykule tematyki można wskazać następujące akty normatywne: decyzję ramową Rady z dnia 15 marca 2001 r. w sprawie pozycji ofiar w postępowaniu karnym ${ }^{24}$, decyzję ramową Rady z dnia 13 czerwca $2002 \mathrm{r}$. w sprawie wspólnych zespołów dochodzeniowo-śledczych ${ }^{25}$, decyzję ramową Rady z dnia 13 czerwca 2002 r. w sprawie europejskiego nakazu aresztowania i procedury wydawania osób między państwami członkowskimi ${ }^{26}$ czy decyzję ramową Rady z dnia 19 lipca 2002 r. w sprawie zwalczania handlu ludźmi ${ }^{27}$.

Nie ulega wątpliwości, że wprowadzanie możliwości wydawania przez instytucje unijne decyzji ramowych doprowadziło do zacieśnienia oraz usprawnienia współpracy w obszarze wymiaru sprawiedliwości państw członkowskich ${ }^{28}$, a to głównie z tej przyczyny, że umożliwiło uniknięcie konieczności przeprowadzania wzmiankowanego już wyżej długotrwałego procesu ratyfikacji, co stopniowo przyczyniało się do harmonizacji unijnego prawa karnego.

Należy jednak stwierdzić, że przywołany instrument prawny również okazał się niewystarczający. Przyczyn takiego stanu rzeczy było kilka, w przeważającej mierze trzeba się ich doszukiwać w nieskutecznej

${ }^{23} \mathrm{Na}$ temat decyzji ramowej jako instrumentu prawnego zob. m.in.: P. Hofmański, S. Zabłocki, Elementy metodyki pracy sędziego w sprawach karnych, Warszawa 2011, s. 370; E. Pływaczewski, E. Guzik-Makaruk, Kilka uwag na temat wpływu decyzji ramowych Rady Unii Europejskiej na kształt prawnokarnego ustawodawstwa w Polsce, "Białostockie Studia Prawnicze" 2014, z. 15, s. 18; S. Biernat, Framework Decision as a Legal Instrument within the Third Pillar, w: The European Arrest Warrant and Its Implementation in the Member State of the European Union, ed. by P. Hofmański, A. Górski, Warszawa 2008.

${ }^{24}$ Dz.Urz. WE L 82 z 22 III 2001 r.

${ }^{25}$ Dz.Urz. UE L 162 z 20 VI 2002 r.

${ }^{26}$ Dz.Urz. UE L 190 z 18 VII 2002 r.

27 Dz.Urz. UE L 203 z 1 VIII 2002 r.

${ }^{28}$ W literaturze przedmiotu wskazywano nawet na zjawisko „amsterdamizacji” działań w zakresie trzeciego filaru, zob. H. Maroń, Integracja europejska a prawo karne, Toruń 2003, s. 45. 
implementacji postanowień decyzji ramowych ${ }^{29}$. Jako przykład można wskazać raport Komisji Europejskiej dotyczący implementacji decyzji ramowej w sprawie pozycji ofiar w postępowaniu karnym, gdzie wskazano, że w 2009 r., siedem lat po ostatecznym terminie implementacji tej decyzji, wciąż żadne albo prawie żadne z państw członkowskich nie transponowało jej postanowień w sposób prawidłowy, a przepisy decyzji nie osiągnęły zamierzonego celu zapewnienia adekwatnej ochrony ofiar w ramach Unii Europejskiej ${ }^{30}$.

Nie chodziło w tym zakresie tylko o sytuacje niewdrożenia postanowień decyzji ramowych do wewnętrznych porządków państw unijnych, ale także o przypadki rozbieżności interpretacji ich postanowień, które mogły być usunięte jedynie w drodze wyroku TS WE. Podobne uwagi kierowane były pod adresem implementacji wspomnianej wyżej decyzji ramowej Rady z dnia 19 lipca 2002 r. w sprawie zwalczania handlu ludźmi. Praktyka pokazała również, że nawet mimo odpowiedniej implementacji przepisy poszczególnych państw członkowskich "inspirowane" regulacjami unijnymi były często nieskuteczne ze względu na brak ich odpowiedniego egzekwowania. Badania pokazują, że poszczególne państwa członkowskie różniły się między sobą w stopniu nie tylko implementacji, ale także właśnie odpowiedniego egzekwowania transponowanych przepisów.

Osobnym problemem był brak bezpośredniego skutku decyzji ramowych oraz niejasna - przynajmniej do czasu wydania orzeczenia w sprawie Pupino ${ }^{31}$ - metoda ich wykładni. Dopiero w przełomowym wyroku z 2005 r. TS WE przesądzil, że obowiązek prowspólnotowej wykładni rozciąga się również na decyzje ramowe oraz inne instrumenty prawne z trzeciego filaru.

Drugim nowym instrumentem wprowadzonym przez Traktat amsterdamski była decyzja, którą Rada mogła wydawać na podstawie art. 34 ust. 2 pkt c. Decyzje te można było przyjmować dla jakichkolwiek celów zgodnych z przepisami tytułu VI (czyli „Postanowień o współpracy

${ }^{29}$ Co wynikało w głównej mierze z braku efektywnych sankcji za niedopełnienie obowiązku prawidłowej implementacji decyzji ramowych.

${ }^{30}$ Zob. więcej: Dyrektywa o prawach ofiar, http://www.victimsprotection.eu/images/ newsletter/newsletter-pl.pdf (dostęp: 19 II 2016).

${ }^{31} \mathrm{~W}$ tym wyroku TS WE de facto potwierdził regułę prymatu prawa wspólnotowego także w odniesieniu do decyzji ramowych, zob. sprawę C-105/03, http://curia.europa.eu/ juris/showPdf.jsf;jsessionid=9ea7d2dc30db414b0499326e4168a9ffa0ac6a2c4df6.e34KaxiLc3qMb40Rch0SaxqTch90?text $=$ \& docid $=59363 \&$ pageIndex $=0$ \& doclang $=$ PL\&mo$\mathrm{de}=$ req \&dir $=\& o c c=$ first $\&$ part=1\& cid=67249 (dostęp: 19 II 2016). 
policyjnej i sądowej w sprawach karnych"), z wyjątkiem zbliżania do siebie przepisów prawnych państw członkowskich. Instrument ten trzeba odróżnić od decyzji wydawanych na podstawie art. 249 Traktatu ustanawiającego Wspólnotę Europejska, które wiążą tylko adresatów, do których sa skierowane, podczas gdy decyzje trzeciofilarowe stanowiły akt generalny. Wprawdzie decyzje te miały charakter wiążący (choć nie miały skutku bezpośredniego), to jednak ze względu na to, że nie mogły być wykorzystywane do zbliżania do siebie przepisów prawa krajowego, ich znaczenie było mniejsze niż decyzji ramowych ${ }^{32}$. Do najistotniejszych aktów prawnych tego typu zaliczyć można: decyzję Rady z dnia 28 lutego 2002 r. ustanawiającą Eurojust w celu zintensyfikowania walki z poważną przestępczością ${ }^{33}$ oraz decyzję Rady z dnia 22 lipca 2002 r. ustanawiającą program ramowy w sprawie współpracy policyjnej i sądowej w sprawach karnych ${ }^{34}$.

Pomimo pewnych usprawnień wprowadzonych na mocy Traktatu amsterdamskiego (oprócz nowych instrumentów należy wspomnieć o objęciu jurysdykcją TS WE ważności i wykładni decyzji oraz decyzji ramowych, wykładni konwencji sporządzonych na mocy tytułu VI, a także ważności i wykładni środków wykonawczych do tych konwencji) skuteczność działań Unii Europejskiej w sprawach karnych wciąż pozostawiała wiele do życzenia. $Z$ tym problemem miał między innymi zmierzyć się Traktat z Lizbony.

\section{Modyfikacja ścigania karnego przez Traktat z Lizbony}

Analiza modyfikacji dokonanych mocą Traktatu lizbońskiego w sposób oczywisty przekracza ramy tej pracy, dlatego też nacisk zostanie położony tutaj jedynie na zmiany związane z podejściem Unii Europejskiej do współpracy w przedmiocie prawa karnego.

W pierwszej kolejności należy zwrócić uwagę, że do Traktatu ustanawiającego Wspólnotę Europejska, którego nazwa została zmieniona na Traktat o funkcjonowaniu Unii Europejskiej, wprowadzony został tytuł „Przestrzeń wolności, bezpieczeństwa i sprawiedliwości”, na który składały się przepisy między innymi dawnego tytułu VI Traktatu o Unii Europejskiej.

\footnotetext{
32 A. Grzelak, op. cit., s. 207-219.

${ }^{33}$ Dz.Urz. UE L 63/1 z 6 III 2002 r.

${ }^{34}$ Dz.Urz. UE L 203/5 z 1 VIII 2002 r.
} 
Zlikwidowano strukturę filarową i usunięto instrumenty prawne charakterystyczne dla dawnego trzeciego filaru - omawiane już wspólne stanowiska, wspólne działania, konwencje, decyzje ramowe - przewidując, że współpraca opierać się będzie na: rozporządzeniach, dyrektywach, decyzjach, zaleceniach i opiniach. W związku z tym zmieniono również procedurę prawodawczą. Przed wejściem w życie Traktatu z Lizbony w omawianej dziedzinie wymagano jednomyślności w Radzie Unii Europejskiej, podczas gdy teraz wystarcza większość kwalifikowana.

Skupiając się w tym miejscu na wybranych uregulowaniach Traktatu o funkcjonowaniu Unii Europejskiej, należy uznać, że kluczowymi przepisami z punktu widzenia rozwoju współpracy w dziedzinie unijnego prawa karnego są uregulowania art. 82 i 83 TFUE. Artykuł 82 ust. 1 TFUE stanowi, że "współpraca sądowa w sprawach karnych w UE opiera się na zasadzie wzajemnego uznawania wyroków i orzeczeń sądowych". Wprowadzenie tego unormowania bez wątpienia stanowi przełom w obszarze europejskiego ścigania karnego, bowiem do tej pory status zasady wzajemnego uznawania i zaufania, mimo jej bezdyskusyjnego znaczenia dla rozwoju współpracy w sprawach karych, był niejasny ${ }^{35}$.

Na szczególną uwagę z punktu widzenia interesującego nas tematu zasługuja ponadto przepisy art. 83 ust. 1 TFUE oraz art. 82 ust. 2 TFUE. Pierwszy z wymienionych przewiduje, że „Parlament Europejski i Rada, stanowiąc w drodze dyrektyw zgodnie ze zwykłą procedurą prawodawczą, mogą ustanowić normy minimalne odnoszące się do określania przestępstw oraz kar w dziedzinach szczególnie poważnej przestępczości o wymiarze transgranicznym, wynikające $z$ rodzaju lub skutków tych przestępstw lub ze szczególnej potrzeby wspólnego ich zwalczania". Do powyższych dziedzin zaliczyć można: terroryzm, handel ludźmi oraz seksualne wykorzystywanie kobiet i dzieci, nielegalny handel narkotykami, nielegalny handel bronia, pranie pieniędzy, korupcję, fałszowanie środków płatniczych, przestępczość komputerową i przestępczość zorganizowaną. W zależności od rozwoju przestępczości Rada może przyjąć decyzję określającą inne dziedziny przestępczości

${ }^{35} \mathrm{Na}$ temat kształtowania się zasady wzajemnego uznawania zob. w szczególności judykaty - „kroki milowe" - TS WE: wyrok z 11 VII 1974 r. w sprawie Benoit i Gustave Dassonville, C-8/74; wyrok z 20 II 1979 r. w sprawie Cassis de Dijon, C-120/78; a także Z. Barwinek, Zasada wzajemnego uznawania w sprawach karnych, Warszawa 2012; M. Górka, Zasada wzajemnego uznawania w prawie Unii Europejskiej, Warszawa 2014, s. 227; A. Górski, A. Sakowicz, Zasada wzajemnego uznawania orzeczeń w Unii Europejskiej, w: Zwalczanie przestępczości w Unii Europejskiej. Wspótpraca policyjna i sądowa w sprawach karnych, pod red. A. Górskiego, A. Sakowicza, Warszawa 2006, s. 411-448; A. Górski, op. cit., s. 43. 
spełniające kryteria, o których mowa w niniejszym ustępie. Rada stanowi jednomyślnie po uzyskaniu zgody Parlamentu Europejskiego.

Zgodnie zaś z art. 82 ust. 2 „w zakresie niezbędnym dla ułatwienia wzajemnego uznawania wyroków i orzeczeń sądowych, jak również współpracy policyjnej i sądowej w sprawach karnych o wymiarze transgranicznym, Parlament Europejski i Rada, stanowiąc w drodze dyrektyw zgodnie ze zwykłą procedurą prawodawcza, mogą ustanawiać normy minimalne. Normy takie uwzględniają różnice między tradycjami i systemami prawnymi Państw Członkowskich.

Dotyczą one:

a) wzajemnego dopuszczania dowodów między Państwami Członkowskimi;

b) praw jednostek w postępowaniu karnym;

c) praw ofiar przestępstw;

d) innych szczególnych aspektów postępowania karnego, określonych uprzednio przez Radę w drodze decyzji; przyjmując taką decyzję, Rada stanowi jednomyślnie po uzyskaniu zgody Parlamentu Europejskiego".

Biorąc pod uwagę powyższe, należy zauważyć, że Unia Europejska na mocy Traktatu $z$ Lizbony postanowiła zharmonizować w określonym zakresie - w drodze dyrektyw - normy prawa karnego materialnego oraz prawa procesowego państw członkowskich. Abstrahując od oceny tego zjawiska, nie sposób nie zauważyć, że harmonizacja norm prawa karnego - czy to materialnego czy procesowego - jest swego rodzaju osobliwościa, fenomenem tworzenia norm prawa karnego przez podmiot niebędący państwem. Nie jest, rzecz jasna, tak, że przed powstaniem Unii Europejskiej nie mieliśmy do czynienia z podobnym zjawiskiem - już wcześniej zawierano traktaty, których przedmiotem były uregulowania karnoprawne. Niemniej jednak należy zwrócić uwagę, że w takich sytuacjach strony przystępujące do umowy międzynarodowej dysponowały pełną swobodą zawarcia takiego porozumienia, wynikającą z ius tractatuum. W przypadku zaś kooperacji w ramach Unii Europejskiej jest inaczej: ze względu na wspomniane zmiany procedury ustawodawczej swoboda ta nie jest już tak duża ${ }^{36}$.

${ }^{36}$ Poruszona kwestia zawsze otwiera dyskusję na temat deficytu demokracji w Unii Europejskiej, w szczególności jeśli weźmie się pod uwagę tak newralgiczny obszar, jakim jest prawo karne. Zob. na ten temat więcej m.in. w: A. Górski, op. cit., s. 219-232. Ogólnie w tym przedmiocie: K. Wojtaszczyk, J. Szymańska, Deficyt demokracji w Unii Europejskiej, Warszawa 2012. 
Omawiana zmiana ukazuje skalę postępu, jaki nastąpił na przestrzeni ostatnich lat w obszarze europejskiego ścigania karnego poprzez odejście od anachronicznego zapatrywania westfalskiego ${ }^{37}$, rozumianego jako przekonanie, że żaden akt władczy jednego państwa (a tym bardziej bytu niepaństwowego) nie powinien mieć jakiegokolwiek skutku na terytorium innego państwa bez jego zgody ${ }^{38}$. Unia Europejska nie tylko tworzy jednolity rynek i obszar wolności, bezpieczeństwa i sprawiedliwości, ale także, a może przede wszystkim, wyznacza nowe ścieżki międzynarodowej polityki karnej.

Nadto wyraźnego podkreślenia wymaga fakt rozszerzenia granic współpracy, jaki dokonał się po wejściu w życie TzL. Wypada zwrócić uwagę na znaczne poszerzenie obszarów, w których działania harmonizujące mogą być w świetle postlizbońskiego porządku prawnego przedsiębrane. Porównanie treści dawnego art. 31 Traktatu o Unii Europejskiej, stwierdzającego lakonicznie "stopniowe przyjmowanie środków ustanawiających minimalne normy dotyczące znamion przestępstw i kar w dziedzinach przestępczości zorganizowanej, terroryzmu i nielegalnego handlu narkotykami", z brzmieniem omawianych wyżej przepisów nie pozostawia wątpliwości co do zasadniczej zmiany w tym zakresie. Wydaje się ponadto, że art. 114 i 115 TFUE także mogą być postrzegane jako potencjalne podstawy traktatowe działań Unii w obszarze współpracy w zakresie prawa karnego, przynajmniej dopóty, dopóki będą przyczyniać się do urzeczywistniania celów rynku wewnętrznego ${ }^{39}$.

\section{Krótka charakterystyka dorobku Unii Europejskiej w zakresie harmonizacji norm prawa procesowego oraz kar minimalnych}

\subsection{Prawa jednostek w postępowaniu karnym}

Koncentrując się na jednej z dziedzin, w których Traktat z Lizbony przewiduje możliwość przyjmowania norm minimalnych, tj. na prawach jednostek w postępowaniu karnym, należy wskazać, że wizja zamierzeń

${ }^{37}$ Na temat przyczyn tego zjawiska zob. np. P. Hofmański, Przyszłość ścigania karnego w Europie, "Europejski Przegląd Sądowy" 2006, nr 12, s. 4-7, i cytowana tam literatura.

${ }^{38}$ A. Górski, op. cit., s. 22-23.

${ }^{39}$ R. Letschert, C. Rijken, Rights of Victims of Crime: Tensions Between an Integrated Approach and a Limited Legal Basis for Harmonisation, "New Journal of European Criminal Law" 2013, vol. 4, iss. 3, s. 253-254. 
prawnych Unii Europejskiej na tej płaszczyźnie została przedstawiona w Rezolucji z 30 listopada 2009 r. ${ }^{40}$ dotyczącej harmonogramu działań mających na celu umocnienie praw procesowych osób podejrzanych lub oskarżonych w postępowaniu karnym ${ }^{41}$. W tym dokumencie przedstawiono sześć środków priorytetowych:

- prawo do tłumaczenia ustnego i pisemnego;

- prawo do informacji o prawach;

- porada i pomoc prawna na etapie postępowania przygotowawczego;

- prawo osoby zatrzymanej do kontaktu z rodzina, pracodawcą i władzami konsularnymi;

- ochrona podejrzanych wymagających szczególnego traktowania;

- Zielona Księga w sprawie tymczasowego aresztowania.

Wypada podkreślić, że przedstawiona wizja nie ma charakteru czysto teoretycznego, ale została już w znacznym stopniu urzeczywistniona, bowiem do tej pory przyjęto trzy dyrektywy:

- dyrektywę Parlamentu Europejskiego i Rady 2010/64/UE w sprawie prawa do tłumaczenia ustnego i tłumaczenia pisemnego w postępowaniu karnym ${ }^{42}$;

- dyrektywę Parlamentu Europejskiego i Rady 2012/13/UE w sprawie prawa do informacji w postępowaniu karnym;

- dyrektywę Parlamentu Europejskiego i Rady 2013/48 UE w sprawie prawa dostępu do adwokata w postępowaniu karnym i w postępowaniu dotyczącym europejskiego nakazu aresztowania oraz w sprawie prawa do poinformowania osoby trzeciej o pozbawieniu wolności i prawa do porozumiewania się z osobami trzecimi i organami konsularnymi w czasie pozbawienia wolności ${ }^{43}$.

Omówienie uregulowań wskazanych tutaj dyrektyw nie mieści się w ramach niniejszego opracowania ${ }^{44}$, niemniej trzeba odnotować, że

${ }^{40}$ Dz.Urz. UE. C 295/1 z 4 XII 2009 r.

${ }^{41}$ Więcej na temat krystalizowania się idei unijnych minimalnych standardów praw podejrzanych i oskarżonych w postępowaniu karnym, począwszy od Zielonej Księgi dotyczącej gwarancji procesowych podejrzanych i oskarżonych w postępowaniach karnych w Unii Europejskiej (COM(2003) 75 final, 19 II 2003), zob. w: A. Gajda, Umocnienie praw jednostki w postępowaniu karnym w Unii Europejskiej a dyrektywa w sprawie dostępu do adwokata, http://kolegia.sgh.waw.pl/pl/KES/kwartalnik/Documents/KES17AG.pdf (dostęp: 15 II 2016).

${ }^{42}$ Dz.Urz. UE L 280 z 26 X 2010 r.

${ }^{43}$ Dz.Urz. UE L 294 z 6 XI 2013 r.

${ }^{44}$ Na temat dyrektywy w sprawie prawa dostępu do adwokata zob. więcej w: A. Gajda, op. cit.; A. Klamczyńska, T. Ostropolski, Prawo do adwokata w dyrektywie 2013/48/UE - tło i implikacje dla polskiego ustawodawcy, „Białostockie Studia Prawnicze” 2014, nr 15, zaś 
bezsprzecznie stanowią one niezwykle interesujący materiał normatywny, szczególnie w kontekście problemu przenikania się i wzajemnego oddziaływania: krajowych rozwiązań procesowych, prawa unijnego oraz porządku strasburskiego. Nie ma wątpliwości co do tego, że ten ostatni był inspiracją przeprowadzanych zmian ${ }^{45}$, a obecnie postrzegany być musi jako "motor napędowy" harmonizacji norm prawa procesowego państw członkowskich Unii Europejskiej ${ }^{46}$.

Sygnalizując zaś dorobek normatywny Unii Europejskiej w przedmiocie praw ofiar przestępstw w postępowaniu karnym, należy wskazać przede wszystkim na:

- dyrektywę Parlamentu Europejskiego i Rady 2012/29/UE z dnia 25 października 2012 r. ustanawiającą normy minimalne w zakresie praw, wsparcia i ochrony ofiar przestępstw (zastąpiła decyzję ramową Rady 2001/220/WSiSW ${ }^{47}$ );

- dyrektywę Parlamentu Europejskiego i Rady 2011/36/UE z dnia 5 kwietnia 2011 r. w sprawie zapobiegania handlowi ludźmi i zwalczania tego procederu oraz ochrony ofiar (zastąpiła decyzję ramową Rady 2002/629/WSiSW ${ }^{48}$ ).

\subsection{Kary minimalne}

Wprawdzie ze względu na rozwój kompetencji ${ }^{49}$ Unii Europejskiej do stanowienia lub harmonizacji norm prawa karnego zagadnienie

odnośnie do prawa do tłumaczenia zob. m.in.: A. Górski, M. Toruński, Zmiany w treści prawa do ttumaczenia w postępowaniu karnym według dyrektywy Komisji i Rady 2010/64/UE, „Białostockie Studia Prawnicze” 2014, nr 15, s. 129-142; C. Nowak, Prawo do korzystania z pomocy ttumacza w europejskim i polskim prawie karnym, "Prokuratura i Prawo” 1998, nr 10.

${ }^{45}$ Por. np. pkt 5 Preambuły do dyrektywy 2010/64/UE.

${ }^{46}$ Wypada jedynie zasygnalizować, że ta ostatnia kwestia nierozerwalnie łączy się ze skomplikowanym problemem realizacji przez prawo unijne wymagań zasady pomocniczości. Wskazania co do zasady pomocniczości znaleźć można w Protokole w sprawie stosowania zasad pomocniczości i proporcjonalności, dołączonym do Traktatu z Amsterdamu. Więcej na temat zagadnienia realizacji zasady pomocniczości w kontekście dyrektywy dotyczącej prawa do tłumaczenia zob. w: A. Górski, M. Toruński, op. cit., s. $133-134$.

${ }^{47}$ Dz.Urz. UE L 315/7 z 14 XI 2012 r.; zob. na ten temat w: Dyrektywa Parlamentu Europejskiego i Rady ustanawiajaca normy minimalne w zakresie praw, wsparcia i ochrony ofiar przestępstw. Komentarz, pod red. E. Bieńkowskiej, L. Mazowieckiej, LEX 2014.

${ }^{48}$ Dz.Urz. UE L 101 z 15 IV 2011 r.

${ }^{49}$ Kompetencji tej kształt nadawał początkowo TS WE, zob. np. sprawę C-265/95 Komisja przeciwko Francji. 
harmonizacji kar nie było obce nauce prawa ${ }^{50}$, jednak należy zaobserwować, że przed wejściem w życie TzL naukowa dyskusja na ten temat, co do zasady, nie toczyła się wokół problematyki harmonizacji kar minimalnych, głównie ze względu na brak wyraźnej podstawy prawnej takiej harmonizacji ${ }^{1}$.

Jednoznaczną zmianę w tym obszarze, jak wspomniano powyżej, przyniósł art. 83 ust. 1 TFUE, który przewiduje kompetencję „ustawodawcy unijnego" do stanowienia norm minimalnych odnoszących się do przestępstw oraz kar w dziedzinach szczególnie poważnej przestępczości o wymiarze transgranicznym. Wspomniana kompetencja znalazła wyraz w projektowanych przez Komisję Europejską oraz obowiązujących już aktach prawnych, gdzie przedstawiono koncepcję harmonizacji minimalnych granic wymiaru kary pozbawienia wolności, i to zarówno górnej, co nie jest nowościa, jak i dolnej, co do tej pory nie miało miejsca.

Przykładem prawa pozytywnego $\mathrm{w}$ przedmiocie sygnalizowanych tutaj rozwiązań może być choćby art. 5 ust. 4 dyrektywy w sprawie prawnokarnych środków ochrony euro i innych walut przed fałszowaniem ${ }^{52}$, który przewiduje, że przestępstwa, których dotyczy ta dyrektywa, są zagrożone karą w maksymalnej wysokości co najmniej 5 lat pozbawienia wolności.

Podobne rozwiązanie zawiera art. 8 ust. 1 lit. a oraz b projektu dyrektywy w sprawie zwalczania nadużyć na szkodę interesów finansowych Unii za pośrednictwem prawa karnego ${ }^{53}$, zgodnie z którym przestępstwa regulowane tym aktem prawnym podlegają sankcji karnej w wymiarze co najmniej 6 miesięcy pozbawienia wolności oraz karze maksymalnej w wymiarze co najmniej 5 lat pozbawienia wolności.

Wydaje się, że do zarysowanej wyżej zasadniczej modyfikacji kompetencji Unii winno się podchodzić z dużą rezerwą z przyczyn, które zostaną węzłowo wskazane w dalszej części artykułu.

${ }^{50}$ I. Dzialuk, O harmonizacji kar minimalnych w prawie Unii Europejskiej, w: Fiat iustitia pereat mundus. Księga jubileuszowa poświęcona Sędziemu Sądu Najwyższego Stanisławowi Zabłockiemu z okazji 40-lecia pracy zawodowej, pod red. P. Hofmańskiego, Warszawa 2014.

${ }^{51}$ Por. jednak art. 31 ust. 1 lit. e Traktatu o Unii Europejskiej w odniesieniu do dawnego trzeciego filaru.

${ }^{52}$ Dz.Urz. UE L 151 z 21 V 2014 r.

${ }^{53}$ Wniosek dotyczący dyrektywy Parlamentu Europejskiego i Rady w sprawie zwalczania nadużyć na szkodę interesów finansowych Unii za pośrednictwem prawa karnego COM/2012/0363 final - 2012/0193 (COD). 


\section{Ocena aktualnych działań Unii Europejskiej w zakresie ścigania karnego}

Należy odnotować, że Traktat z Lizbony zakreślił szersze ramy prawne, które zapewniły nowe możliwości rozwijania prawodawstwa Unii Europejskiej w obszarze prawa karnego. Bez wątpienia organy unijne wyposażone zostały w nieznane dotąd na płaszczyźnie penalnej instrumenty prawne, pozwalające na bardziej skuteczne niż do tej pory działania legislacyjne. Za cel polityki kryminalnej postawiono sobie walkę z przestępczością oraz wzmacnianie w obywatelach państw członkowskich Unii przekonania o tym, że żyją w przestrzeni wolności, bezpieczeństwa i sprawiedliwości.

Powyższe cele realizowane są przez Unię niejako dwutorowo. Z jednej strony wdrażane są systematycznie instrumenty o charakterze represyjnym $^{54}$, z drugiej zaś - paralelnie wciela się w życie mechanizmy gwarancyjne dla podejrzanych i oskarżonych, które mają za zadanie zapewniać efektywną realizację przysługującego im prawa do rzetelnego procesu, przewidzianego nie tylko przez Konwencję o Ochronie Praw Człowieka i Podstawowych Wolności ${ }^{55}$ (art. 6 EKPC), ale także przez Kartę Praw Podstawowych Unii Europejskiej ${ }^{56}$ (art. 47 ust. 2 KPP UE), która - przypomnijmy - na mocy Traktatu z Lizbony uzyskała moc prawną równą TUE oraz TFUE. Zdecydowano więc w ramach Unii Europejskiej, że zacieśnianie współpracy sądowej i policyjnej nie może odbywać się kosztem praw oskarżonego, podejrzanego oraz pokrzywdzonego, a zbliżanie ustawodawstw państw członkowskich w dziedzinie prawa karnego musi pociągać za sobą ustalenie pewnego minimalnego standardu ochrony praw jednostki.

Jednocześnie Unia Europejska zdaje sobie sprawę, że wyznaczanie tego standardu gwarancji procesowych odbywać się musi stopniowo. Całościowe uregulowanie przedmiotowego problemu ze względu przede wszystkim na kontrowersje wokół katalogu praw proceduralnych, które miałyby być zapewnione, okazało się niemożliwe ${ }^{57}$. Z tych

${ }^{54}$ Por. na przykład dyrektywę Parlamentu Europejskiego i Rady nr 2014/41/UE z dnia 3 IV 2014 r. w sprawie europejskiego nakazu dochodzeniowego w sprawach karnych (Dz.Urz. UE L 130 z 1 V 2014 r.) czy choćby wspomniane instrumenty harmonizujące kary minimalne.

${ }^{55}$ Dz.U. 1993 Nr 61, poz. 284, dalej „EKPC”.

${ }^{56}$ Dz.Urz. UE C 83/389 z 30 III 2010 r., dalej „KPP UE”.

${ }^{57}$ Dlatego też ostatecznie fiaskiem zakończyły się prace nad wnioskiem decyzji ramowej Rady w sprawie niektórych praw proceduralnych w postępowaniu karnym 
powodów akceptuje się obecnie strategię stopniowego przyjmowania przepisów, które będą sprzyjać systematycznemu budowaniu i pogłębianiu wzajemnego zaufania między państwami członkowskimi Unii Europejskiej.

Nie negując w żadnym razie niewątpliwie wartościowych idei, które legły u podstaw opisywanych działań Unii Europejskiej, a także znacznego postępu, który dokonał się na płaszczyźnie unijnego prawa karnego, należy jednak zwrócić uwagę na kilka problemów przyjętej przez Unię Europejską strategii jego rozwoju. Po pierwsze, trzeba zauważyć, że Unia Europejska, stawiając sobie za zadanie harmonizację przepisów prawa procesowego państw członkowskich, miała na celu - jak wskazano - ustalenie minimalnego standardu ochrony praw jednostki, co - jak się wydaje - jest naturalną konsekwencją zagwarantowania obywatelom unijnym, korzystającym ze swobody poruszania się, wygody psychicznej, która ma polegać na tym, że wyjeżdżając do innego kraju Unii Europejskiej, będą mieli komfort posiadania minimalnego poziomu ochrony prawnej. Innymi słowy, zwiększenie standardu tej ochrony ma w konsekwencji przyczynić się do urzeczywistnienia idei swobody przepływu osób. O ile w przypadku praw procesowych podejrzanego przedstawione rozumowanie może być poddane pod rozwagę, to wydaje się, że w kontekście praw pokrzywdzonego nie wytrzymuje ono ciężaru krytyki. Należy bowiem zwrócić uwagę, że obywatel jednego państwa członkowskiego, wyjeżdżając do innego kraju Unii, może w ogóle nie zdawać sobie sprawy, że padł ofiarą przestępstwa, a tym samym, że posiada status pokrzywdzonego. Oczywiście, można argumentować, że ogromna liczba przestępstw we wszystkich państwach członkowskich Unii Europejskiej ma podobny charakter, jednak nie można tracić z pola widzenia okoliczności, że różnice pomiędzy systemami prawnymi poszczególnych państw członkowskich są w wielu przypadkach ogromne.

Zilustrować to można następującymi dwoma przykładami. Nie we wszystkich systemach prawnych państw członkowskich Unii Europejskiej - jak ma to miejsce w prawie polskim ${ }^{58}$ - wypadek drogowy z nieumyślnym skutkiem śmiertelnym jest przestępstwem, bowiem

w Unii Europejskiej (Proposal for a Council Framework decision on certain procedural rights in criminal proceedings throughout the European Union, $\operatorname{COM(2004)~} 328$ final, Brussels, 28 IV 2004). Zob. Komunikat prasowy z 2807. posiedzenia Rady UE ds. WSiSW, Luksemburg, 12-13 VI 2007 r., dok. 10267/07, Presse 125.

${ }^{58}$ Zob. art. 177 § 2 Kodeksu karnego. 
w niektórych z nich taki czyn realizuje znamiona zaledwie wykroczenia. Kolejny przykład dotyczy wyłącznie prawa angielskiego, w którym do początku lat dziewięćdziesiątych XX w. ${ }^{59}$ wykluczano możliwość popełnienia przestępstwa zgwałcenia małżeńskiego, podczas gdy w polskim prawie taką koncepcję przyjęto już w 1932 r. Powyższe przykłady pokazuja, jak znaczące mogą być różnice w materialnym prawie karnym różnych państw członkowskich. W związku z tym nasuwają się pytania, czy harmonizacji przepisów prawa procesowego nie powinna poprzedzać, choćby w minimalnym zakresie, harmonizacja przepisów prawa karnego materialnego państw członkowskich Unii, a także czy taka harmonizacja jest de lege lata w ogóle możliwa.

Unia Europejska istotnie podejmuje działania zmierzające do harmonizacji przepisów materialnego prawa karnego, ale dotyczących wyłącznie przestępstw o charakterze transgranicznym, przestępstw o kształcie "europejskim" ${ }^{60}$, co w rozpatrywanym tutaj kontekście ma zdecydowanie mniejsze znaczenie. Zresztą obserwując działania prawodawcze Unii Europejskiej w innych dziedzinach, można dostrzec, że co do zasady w pierwszej kolejności ujednolicano albo harmonizowano prawo materialne, zostawiając państwom członkowskim w ramach autonomii proceduralnej swobodę odnośnie do procedury, w przypadku zaś przestrzeni wolności, bezpieczeństwa i sprawiedliwości kolejność ta wydaje się odwrócona. Należy przyznać, że przedstawiona tutaj specyfika "Współpracy wymiarów sprawiedliwości w sprawach karnych" wynika po części $z$ charakteru zasady wzajemnego uznawania i zaufania oraz jej wpływu na kształtowanie się działań unijnych na omawianej płaszczyźnie. Niemniej jednak nie sposób uznać, że zasada ta rozwiewa obecnie wszystkie wątpliwości rodzące się $\mathrm{w}$ związku z podniesionym problemem ${ }^{61}$.

Konieczne jest również zwrócenie uwagi na - być może trywialny, choć możliwe, że najważniejszy - aspekt omawianego zagadnienia,

${ }^{59}$ Por. przełomową sprawę R. v.R., http://www.bailii.org/uk/cases/UKHL/1991/12. html (dostęp: 19 II 2016), w której przesądzono, że zgwałcenie jest możliwe również w małżeństwie. Więcej na temat zgwałcenia w common law zob. w: A. Michalska-Warias, Podstęp przy zgwałceniu w prawie polskim oraz angielskim i amerykańskim, "Studia Iuridica Lublinensia" 2014, t. XXI, s. 129-144.

${ }^{60}$ I. Dzialuk, op. cit., s. 113.

${ }^{61}$ L.K. Paprzycki podkreśla, że jednym z celów wprowadzenia tej zasady była chęć ochrony krajowych porządków prawnych przed zbyt daleko idącą harmonizacją, por. L.K. Paprzycki, Przyszłość europejskiego prawa karnego, "Palestra” 2007, nr 9-10, s. 49 i n.; podobnie: C. Nestler, Europäisches Strafprozessrecht, "Zeitschrift für die gesamte Strafrechtswissenschaft" 2004, Bd. 116, H. 2, s. 336-337. 
a mianowicie na problem skuteczności implementacji przyjmowanego przez Unię Europejską prawa. Należy odnotować, że poprzednie próby zbliżania ustawodawstw państw członkowskich w zakresie prawa karnego kończyły się, co do zasady, fiaskiem, głównie ze względu na niepełną i niedokładną implementację prawa, co w konsekwencji powodowało jego nieskuteczne egzekwowanie. Odpowiedzią na tę bolączkę w zamyśle „europejskiego prawodawcy” ma być wprowadzenie instrumentu dyrektywy, która charakteryzuje się między innymi bezpośrednim skutkiem. Nadal pozostaje jednak wattpliwość, czy środek ten okaże się wystarczający.

Nie szukając daleko, wystarczy podać polski przykład - pomimo że dawno już minął czas na implementację dyrektywy dotyczącej prawa oskarżonego oraz podejrzanego do tłumaczenia ustnego i pisemnego, polski ustawodawca do tej pory nie implementował wielu jej szczegółowych rozwiązań ${ }^{62}$, jak choćby instytucji kontroli jakości dostarczonego tłumaczenia ${ }^{63}$. Banalnym, choć wydaje się, że w pełni uprawnionym wnioskiem będzie zatem stwierdzenie, iż sukces konceptu unijnego prawa karnego będzie w znacznym stopniu zależeć od sprawnej implementacji oraz odpowiedniej egzekucji norm prawnych.

Pewien niepokój z punktu widzenia konieczności zapewnienia wewnętrznej spójności krajowych systemów represji karnej mogą budzić również sygnalizowane $\mathrm{w}$ tej pracy rozwiązania dotyczące harmonizacji kar minimalnych. Odkąd Unia Europejska ma kompetencję do harmonizacji kar minimalnych, aktualne jest pytanie o niezbędność takiego instrumentu w kontekście osiągnięcia celów innych niż osiągane przy wykorzystaniu dotychczas stosowanych metod (przede wszystkim harmonizacji dolnych granic kar maksymalnych). Wskazuje się w doktrynie $^{64}$, że spośród analizowanych w nauce prawa karnego celów sankcji (sprawiedliwościowego, ogólnoprewencyjnego, szczególnoprewencyjnego i kompensacyjnego) dotychczasowe środki harmonizacji w prawie europejskim koncentrowały się na celach prewencyjnych. Tymczasem wydaje się, że podejmowane przez Unię Europejską działania prawne

${ }^{62}$ Choć trzeba przyznać, że tzw. Wielka nowelizacja, która weszła w życie 1 VII 2015 r., poczyniła krok naprzód w kontekście transponowania rozwiązań tej dyrektywy. Por. np. znowelizowany art. $244 \S 2$ Kodeksu postępowania karnego, który gwarantuje prawo do tłumaczenia już na etapie zatrzymania.

${ }^{63}$ Por. art. 2 ust. 5 oraz art. 3 ust. 5 dyrektywy 2010/64/UE.

${ }^{64}$ M. Szwarc-Kuczer, Kompetencje Unii Europejskiej $w$ dziedzinie harmonizacji prawa karnego materialnego, Warszawa 2011, s. 178, za: I. Dzialuk, op. cit., s. 113. 
w zakresie harmonizacji kar minimalnych mają na celu przeciwdziałanie zróżnicowanej odpowiedzialności za czyny, których definicje zostały ujednolicone w unijnym prawie, tzn. doprowadzenie do sytuacji, w której dolegliwość kar wymierzanych za podobne czyny zabronione w różnych państwach członkowskich będzie zbliżona. Oznacza to, że harmonizacja nie jest motywowana wyłącznie celami prewencyjnymi, ale zmierza też do osiągnięcia celów sprawiedliwościowych.

W związku z powyższym nasuwa się pytanie, czy harmonizacja dolnych i górnych granic kar za przestępstwa jest wystarczającym środkiem do osiągnięcia tych zamierzeń. Można zasadnie sądzić, że odpowiedź jest negatywna. Nie chodzi bowiem o nominalny wymiar kary, ale o rzeczywiście wymierzaną dolegliwość prawnokarną. Ta ostatnia jest jednak uzależniona od bardzo wielu czynników, zarówno regulacji ustawowych, jak i praktyki ich stosowania. Wśród najważniejszych czynników normatywnych należy wymienić, często bardzo odmienne w poszczególnych państwach członkowskich, ogólne dyrektywy wymiaru kary, środki probacyjne, uregulowania dotyczące sposobu wykonania i modyfikacji kary (instrumenty prawne charakterystyczne dla postępowania wykonawczego ${ }^{65}$. Ponadto pełne osiągnięcie celu sprawiedliwościowego wymagałoby uwzględnienia praktyki stosowania wyżej wymienionych uregulowań w poszczególnych państwach członkowskich, gdyż nawet bardzo odmienne regulacje odpowiedzialności karnej mogą czasem prowadzić do podobnych rezultatów.

„Ustawodawca unijny”, nakreślając założenia współpracy, zdaje się nie uwzględniać zróżnicowania systemów represji karnej poszczególnych państw członkowskich, a mechaniczne przenoszenie zharmonizowanych sankcji z dyrektyw może tylko zaburzyć wspomnianą spójność wewnętrzną krajowych systemów karnych ${ }^{66}$, jednocześnie nie gwarantując rzeczywistej realizacji celów sprawiedliwościowych.

\section{Podsumowanie}

Konkludując, wypada uznać, że opisane powyżej wątpliwości dotyczące ostatnich działań Unii Europejskiej w dziedzinie "Współpracy wymiarów sprawiedliwości w sprawach karnych" powoduja, iż należy

${ }^{65}$ I. Dzialuk, op. cit., s. 114.

${ }^{66}$ Więcej na temat wątpliwości związanych z zagadnieniem harmonizacji kar minimalnych zob. ibidem. 
z dużą ostrożnością przyglądać się próbom harmonizacji prawa karnego państw Unii Europejskiej. Nie oznacza to, oczywiście, że wysiłki te winny zostać ograniczone, bowiem bez wątpienia proces internacjonalizacji prawa karnego, którego jesteśmy świadkami, jest nieunikniony. Wydaje się natomiast, że Unia powinna położyć większy nacisk na to, by jej prawodawcza aktywność na polu prawa karnego była bardziej spójna zarówno z dotychczas prowadzoną polityka, jak i z systemami represji karnej poszczególnych państw członkowskich.

\section{CRIMINAL PROSECUTION IN THE EUROPEAN UNION BEFORE AND AFTER THE LISBON TREATY - SELECTED ISSUES}

\section{Sum mary}

Current legislative activity of the European Union performed under Title V, Chapter 4 of the Treaty on the Functioning of the European Union: "Judicial cooperation in criminal matters" is part of a wider process of internationalisation of criminal law. It shows a paradigm shift of this branch of law, which until now has, first and foremost, been a product of national legal systems. The article discusses selected issues concerning the regulation of criminal prosecution under European Union law. Due to the fact that the present shape of this regulation is the result of a long process of numerous legislative activities as well as various non-legislative forms of international cooperation, the article is not limited to the discussion of the current state of the criminal prosecution in the EU, but takes into account the historical emergence of various institutions, both before and after the establishment of the European Union.

Its first part presents the historical development of instruments designed to cope with crime, which the European Community and then the European Union had at their disposal. This part has two objectives: to describe the difficulties encountered when the first attempts to coordinate the fight against crime at the European level were undertaken and to show the significance of the progress that has been made in this area in recent years. After that, selected issues concerning the harmonisation of rules governing the procedural rights of suspects and defendants in criminal proceedings are discussed. The issue of minimum standards relating to penalties is also raised. The concluding part of the article assesses, whether the path of internationalization of criminal law chosen by the Member States in the post-Lisbon reality is justified.

Keywords: area of freedom, security and justice - judicial cooperation in criminal matters - Europeanisation of criminal law 